Assuming the Burden 
FROM INDOCHINA TO VIETNAM: REVOLUTION AND WAR IN A GLOBAL PERSPECTIVE

Edited by Fredrik Logevall and Christopher E. Goscha

I. Assuming the Burden: Europe and the American Commitment to War in Vietnam, by Mark Atwood Lawrence 


\section{Assuming the Burden}

Europe and the American Commitment to War in Vietnam

Mark Atwood Lawrence 
Portions of this book were published in an earlier form as "Transnational Coalition Building and the Making of the Cold War in Indochina, 1947-1949" in Diplomatic History 26, no. 3 (summer 2002): 453-480, and are reproduced here by permission of Blackwell Publishing Ltd.

University of California Press

Berkeley and Los Angeles, California

University of California Press, Ltd.

London, England

(C) 2005 by The Regents of the University of California

Library of Congress Cataloging-in-Publication Data

Lawrence, Mark Atwood.

Assuming the burden : Europe and the American commitment to war in Vietnam/Mark Atwood Lawrence.

p. cm. - (From Indochina to Vietnam : revolution and war in a global perspective; v. I)

Includes bibliographical references and index.

ISBN 0-520-243 I 5-3 (cloth : alk. paper)

I. Indochina-History-I945- 2. Indochinese War, I946-I954. 3. United States-Foreign relationsFrance. 4. France-Foreign relations-United States.

5. United States-Foreign relations-Vietnam.

6. Vietnam-Foreign relations-United States.

7. France-Foreign relations-Great Britain. 8. Great Britain-Foreign relations-France. I. Title. II. From Indochina to Vietnam; v. I. III. Series.

$\mathrm{DS}_{55} \mathrm{~L}_{5} \mathrm{~L}_{3} 85 \quad 2005$

959.704'I 2 -dc22

2004020239

Manufactured in the United States of America

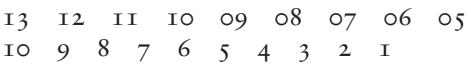

The paper used in this publication meets the minimum requirements of ANSI/NISO Z39.48-I992 (R I997)

(Permanence of Paper). 
For my mother,

whose memory inspires me in all things, and for my father,

who made all things possible 
This page intentionally left blank 